\title{
Scandinavian long-term care financing
}

\section{Martin Karlsson}

Technische Universität Darmstadt

\section{Tor Iversen}

Henning Øien

Department of Health Management and Health Economics,

Health Economics Research

Programme, University of Oslo

\section{UNIVERSITY}

\section{OF OSLO}

HEALTH ECONOMICS

RESEARCH PROGRAMME

Working paper 2010: 2

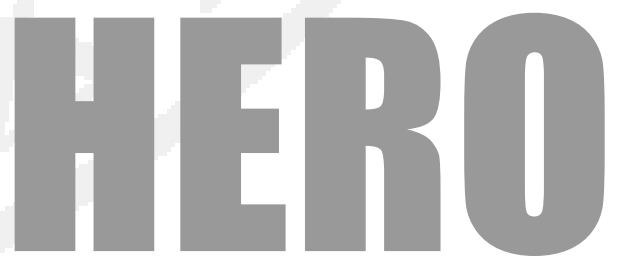




\title{
Scandinavian long-term care financing
}

\author{
Martin Karlsson \\ Chair of Applied Econometrics \\ Technische Universität Darmstadt \\ E-mail: karlsson@ @wl.tu-darmstadt.de \\ Tor Iversen \\ Henning Øien \\ Department of Health Management and Health Economics, University of Oslo \\ P.O. Box 1089 Blindern, NO-0317 Oslo, Norway \\ E-mail: tor.iversen@medisin.uio.no / henning.oien@medisin.uio.no
}

June 2010

\section{Health Economics Research Programme at the University of Oslo HERO 2010}

Keywords: $\quad$ long term care; financing; welfare state, Scandinavia

JEL classification: $\mathrm{H} 42 ; \mathrm{H} 51 ; \mathrm{I} 11 ; \mathrm{I} 18 ; \mathrm{J} 14$ 


\begin{abstract}
In this paper, we compare and analyse the systems for financing long-term care for older people in the Scandinavian countries - Denmark, Norway and Sweden. The three countries share common political traditions of local autonomy and universalism, and these common roots are very apparent when the financing of long-term care is concerned. Nevertheless, the Scandinavian systems for long- term care (LTC) exhibit some important deviations from the idealized "universal welfare state" to which these countries are normally ascribed.

For example, user charges tend to be strongly dependent on earnings, which is incoherent with the general norm of flat-rate public services. Also, there is significant regional variation in the level of services provided, which is in direct contrast with the universalist ambitions.

Overall, the Scandinavian countries distinguish themselves through their very high reliance on public spending in long-term care. It is unclear to what extent the Scandinavian model for financing of long term care will be sustainable as demographic change progresses in the next few decades.
\end{abstract}




\section{Introduction}

The Scandinavian countries - Denmark, Norway and Sweden - share a common history and common political traditions, which has led to very similar systems for social care being introduced in the three countries. This goes for the division of roles and responsibilities between different public bodies, as well as for the national policy objectives that have been laid down in various pieces of legislation. Thus, all three countries pursue the general goal of providing local care services free of charge to everyone in need, independently of their financial circumstances.

Up to the first half of the last century, long-term care in all Scandinavian countries was provided almost exclusively by families. Only for those lacking family members and financial means, municipalities offered care in public poorhouses. Starting in the late 1940s, the public involvement in long-term care evolved from being aimed at poor elderly to a more general approach. The pioneers were Sweden and Denmark, whereas Norway, which at that time was the poorest of the three countries, enacted reforms with a few years of delay (Daatland and Sundström, 1997).

In Denmark, nursing homes which were distinct from the traditional poorhouses started to appear in the 1920s, but the first piece of legislation that introduced universal principles for elderly care was introduced in 1949. The main goal of the 1949 Act was to provide temporary home care for infirm housewives; however, the scheme was extended to cover temporary needs of frail older people as well. In Sweden, municipalities were obliged to offer care in nursing homes starting in the late 1940s. This increased reliance on the public sector was confirmed by a revision of the law in 1956, after which adult children had no formal responsibilities for their parents. In Norway, a similar law was enacted in 1964 (St.meld.nr.25, 2005-2006).

Around 1950, the Swedish economy got overheated, and social reforms were brought to a standstill. Consequently, no more public nursing homes were built. To compensate for this, volunteer organisations started offering domiciliary care. This care was not means-tested, but offered to all elderly in regions where these organisations were operating. It soon turned out, though, that the volunteer organisations would not be able to carry out the expansion needed in domiciliary care. Thus, over the next decade, municipalities overtook ever more responsibility - from volunteer organisations as well as from family members. After government grants for domiciliary care had been introduced in 1964, a rapid expansion of these services took place (Söderström et al, 2001). Also in Denmark and Norway, the 1960s and 1970s were characterised by a rapid expansion of formal long- term care (LTC) services (Daatland and Sundström, 1997).

During the first post-war decades, LTC services went through a gradual metamorphosis in all three countries. The traditional "old age homes" became increasingly controversial, and ever more emphasis was put on dignity of the users and on the quality of care. Reformed care homes with a stronger focus on medical care were introduced. Also, there was a clear trend towards higher staff/user ratios, and the proportion of users with single rooms increased continuously from the 1960 s to the 1980s in all three countries (Daatland, Platz and Sundström, 1997).

The public provision of domiciliary care in Sweden peaked in 1978, with 352000 clients. The number of places in public nursing homes reached its peak at about the same time. In Denmark, the peak was also reached at around the same time, whereas in Norway, the number of beds in nursing homes kept on increasing until the late 1980s (Daatland, Platz and Sundström, 1997). After that, the 
expansion of earlier decades has been reversed. In the 1980s, a retreat of public involvement in long-term care was driven by a marked improvement in the health status of elderly, improved living conditions as well as the awareness that there had been some oversupply in the 70 s.

In the 1990s, Sweden went through its deepest recession since the 1930s. The economic crisis caused severe financial problems in the public sector. As a consequence, the reductions in public provision of long-term care continued, and care was concentrated on the neediest. At the same time, the Swedish model with public monopolies was challenged, and some municipalities introduced purchaser/provider organisations as well as voucher systems for domiciliary care. During the nineties, the share of private caregivers doubled. In Denmark, the long-term trend towards deinstitutionalisation has been almost as strong as in Sweden (Hansen, 2000), whereas in Norway only a small reduction in the number of nursing home beds has been observed (St.meld.nr.25, 20052006).

Since the late 1990s, the financial situation of local authorities in Sweden has been improving almost continuously, which has enabled them to halt some of the downwards trends in the provision of long-term care services. Some other trends from the 1990s have continued unabated, however, such as the ever increasing market share of private providers. Indeed, the current national government actively supports the introduction of consumer choice models at the local level, and has provided earmarked funds for this purpose. In Denmark, the government introduced a uniform system for consumer choice already in 2002 (Ministry of Interior and Health 2005), whereas choice of provider continues being an exception in Norway, in particular for nursing services.

Other important innovations of the last decade are the tightened regulation of user fees and means testing procedures in Sweden, and a cohabitation guarantee stipulating that spouses shall be offered institutional care in the same facilities. In Denmark, a radical restructuring of the municipal sector was undertaken in 2007, when the number of municipalities was reduced from 271 to 98 . The main objective of this reform was to create units large enough to provide public services in an efficient manner. Furthermore, a major quality reform is under way in Denmark, which aims at strengthening the rights of individual users and provides extra funding for quality improvements (Schulz, 2010).

The rest of this chapter is organised as follows. In the next section, we provide a general overview of Scandinavian systems for long-term care. After that, the role of taxes is discussed in section 3 , along with a brief description of the national systems for risk adjustment. In the following section, we discuss the role of user charges in the funding of LTC in Scandinavia. The final section concludes and provides a general discussion of the main features of the Scandinavian systems from an economic point of view, with particular emphasis on their efficiency and equity. Although our main emphasis is on Sweden throughout, we also aim at comparing and contrasting the Swedish case with LTC in Norway and Denmark. It should be noted that there are no insurance policies for LTC costs available on the market in any of the countries, and hence taxes and out-of-pocket payments are exhaustive as sources of funding. 


\section{Overview of Scandinavian LTC systems}

\subsection{A Scandinavian Model?}

There is a long tradition in the social sciences of classifying different types of welfare regimes, such as Titmuss' (1974) distinction between marginal (Anglo-Saxon), industrial achievement (continental Europe) and institutional (Scandinavia) welfare states. The most well-known typology is probably that of Esping-Andersen (1990), which divides welfare states into Corporatist, Liberal and Social Democrat. A further typology was provided by Korpi and Palme (1998), who distinguish no less than five different types of welfare state regimes. No matter which typology chosen, the countries covered in this chapter are always part of the same category, which is referred to as the institutional, Social Democratic, Scandinavian, universal or encompassing model.

The defining traits of this Scandinavian welfare model, according to Esping-Andersen, are, firstly, the existence of highly de-commodifying and universalistic programmes; secondly, equal rights of blueand white-collar workers and thirdly, all strata are incorporated in one universal insurance system, but benefits are graduated according to earnings. Korpi and Palme (1998), on the other hand, define their "encompassing" welfare state as a model that combines earnings-related benefits with universalism, providing basic security to all citizens and earnings-related benefits to the working population. Finally, Rothstein (1998) mentions the provision of publicly provided universally available services as one out of three defining characteristics of the universal Swedish welfare state - the two other being a system of flat rate benefits tied to citizenship (e.g. basic pensions) and a mandatory social insurance system (e.g. sick pay).

Obviously, all these typologies represent ideal types, and it should be expected that each real-world welfare state will exhibit deviations from these criteria. As far as long-term care is concerned, there are certainly some notable deviations from the principles of the "universal" or "encompassing" welfare model. Firstly, all the Scandinavian countries have elements of means-testing in the provision of care services: higher fees are charged from those who earn more, at least for some types of services. Secondly, only the availability of long-term care services is universal, whereas there tend to be no universal principles for how needs assessment is to be carried out, how needs are mapped into care packages, or for the quality of services. This is in clear contrast with the countries that have a social insurance system for LTC, and where all these issues are regulated by law (Wittenberg and Malley, 2007).

In an attempt to categorise European models for social care, Anttonen and Sipilä (1996) suggested a division into three different categories. According to this classification, the Scandinavian countries practise the state responsibility model, where local authorities are responsible for the provision of care services, which are universal and widely available. This model is contrasted with the family care model (Southern Europe) with families as main care providers, and the subsidiary model (The Netherlands, Belgium, Germany and France) where the family also plays an important role, but where substitutes for family care are available when necessary. However, the value added by this classification is questionable since it is based entirely on one single dimension of very complex systems for long-term care; i.e., who is the primary provider of care. Furthermore, it wrongly gives the impression that family care is of limited importance in Scandinavia, which is not correct in general. 


\subsection{Governance}

In all three countries, municipalities have the responsibility of financing and providing long-term care, whereas the national government is responsible for overall control and for establishing the broad legislative and financial framework for health and social policy, including care for the elderly. The responsibilities of municipalities as regards LTC are regulated in Social Services Acts. They typically state that every resident who is in need has a right to home-based or institution-based care. Municipalities are further obliged to actively investigate needs in the local population, and to promote good living conditions in other ways. Furthermore, all three countries have the explicit objective to make it possible for older people to stay at home and live independently as long as possible (Socialstyrelsen, 2002).

Although the structure of governance is almost identical in the three countries, there is nevertheless an important difference in the degree of decentralisation of the local democracy. In Sweden, the emphasis has traditionally been on economies of scale, and in the post-war era there were several waves of restructuring of the municipal sector to create units large enough to be able to carry out their tasks effectively. Thus, the total number of Swedish municipalities has decreased by almost 90 per cent since 1950 (Daatland and Sundström, 1997). In Norway, on the other hand, the emphasis has been much more on local democracy and on keeping a high level of services also in remote areas. In Denmark, a major reform of the governance structure was undertaken in 2007, where the number of municipalities was reduced from 271 to 98 . Consequently, Norway has the smallest municipal units (430 municipalities on a population of 4.9 million), Sweden is an intermediate case (290 municipalities on 9 million people), and Denmark has the largest units: 5.5 million inhabitants are distributed over 98 municipalities.

\subsection{The LTC Sector}

To get a picture of the size and importance of the LTC sector in Scandinavia, services of long-term nursing care is presented in Table 1 as a percentage of GDP. The numbers include expenditure on day care and in-patient care in nursing homes and long-term nursing care at home. In 2006 the OECD average of LTC expenditure was $0.8 \%$, this puts Denmark and Norway way above the average and Sweden just below.

Table 1. Health care expenditure on LTC as a percentage of GDP. ${ }^{1}$

\begin{tabular}{|c|c|c|c|}
\hline Year & Denmark & Norway & Sweden \\
\hline 2003 & 1.96 & 2.37 & 0.72 \\
\hline 2004 & 2.02 & 2.20 & 0.72 \\
\hline 2005 & 2.07 & 2.14 & 0.71 \\
\hline 2006 & 2.07 & 2.14 & 0.70 \\
\hline 2007 & 2.00 & n.a. & 0.70 \\
\hline
\end{tabular}

\footnotetext{
${ }^{1}$ Source: EUROSTAT 2010. The numbers are based on the System of Health Accounts (SHA), a system developed jointly by OECD, WHO and EUROSTAT. The data include expenditure on day care and in-patient care in nursing homes and long-term nursing care at home. Long term care is usually a mix of medical (including long-term nursing care) and social services. SHA only includes the medical part of long-term care expenditure.
} 
The most striking feature of these numbers is that Sweden on average lies approximately 1.35 percentage points below Denmark and Norway. Although the SHA is the dominant source for comparison of health expenditure across countries within the $O E C D$, there are several reasons why the LTC expenditure numbers should be viewed with scepticism. According to Søgaard (2009) longterm care expenditure is the least reliable component of the SHA. The reason is that the definitions and measurement instructions for LTC expenditure are so vague that they leave room for wide interpretations and consequently, the numbers reported seem to be inconsistent across countries. Thus, the OECD average should be treated with caution. With regards to the Scandinavian countries, Søgaard (2009) classifies Denmark and Norway as using a broad definition focusing on care and personal assistance, while Sweden uses a narrow medical/nursing definition. Thus, there is a concern of underreporting by Sweden compared to Denmark and Norway. To compensate, we have also included numbers for Sweden from the Swedish Association of Local Authorities and Regions, which uses a broader definition of LTC expenditures, in Table 2 . The total cost for publicly financed longterm care in Sweden was SEK 87 bn. (€8.9 bn.) in 2007, which corresponds to 2.8 per cent of GDP. In real terms, there was an increase by 1.7 per cent in real terms on the previous year (SALAR, 2009). Over the past decade, Swedish public expenditure on long-term care has fallen as a proportion of GDP and also as a proportion of total operating costs in the local authorities. This reduction in spending has occurred even though the proportion of older people in the population has increased somewhat. The share of local public expenditure devoted to long term-care in Denmark is similar (Statskontoret 2009).

Table 2. Trends in operational costs for local authorities in Sweden (Source: SALAR 2009)

\begin{tabular}{|rrr|r|r|}
\hline \multicolumn{2}{|l}{ Year } & \multicolumn{2}{c}{ Costs in 2007 prices $(€)$} & \multicolumn{2}{c|}{ Elderly care as a share of } \\
Total & Elderly Care & Total Costs & GDP \\
\hline 2000 & 41.76 & 8.97 & $21.5 \%$ & $2.99 \%$ \\
\hline 2001 & 42.37 & 9.12 & $21.5 \%$ & $3.07 \%$ \\
\hline 2002 & 43.24 & 9.24 & $21.4 \%$ & $3.13 \%$ \\
\hline 2003 & 43.27 & 9.17 & $21.2 \%$ & $3.11 \%$ \\
\hline 2004 & 43.72 & 8.75 & $20.0 \%$ & $3.03 \%$ \\
\hline 2005 & 44.13 & 8.61 & $19.5 \%$ & $2.94 \%$ \\
\hline 2006 & 45.13 & 8.73 & $19.3 \%$ & $2.88 \%$ \\
\hline 2007 & 46.13 & 8.88 & $19.2 \%$ & $2.84 \%$ \\
\hline
\end{tabular}

Out of total LTC costs, the main part is made up by institution-based care (61.3 per cent); homebased care accounts for 37.1 per cent and preventive activities 1.6 per cent. Throughout the nineties, the share of institution-based care increased (Swedish Ministry of Health and Social Affairs, 1999), but since 2002, the proportion spent on institutional care has decreased (SALAR, 2009).

\subsection{Services Provided}

In Sweden, municipalities offer home help services, daytime community activities and similar social services to assist elderly living at home. Since 1992, municipalities also are responsible for local nursing homes and some other care institutions. At the same time, a new general term was introduced for all kinds of accommodating institutions under the responsibility of municipalities: "special housing". This term includes nursing homes, residential care facilities such as old age homes, service houses, or group homes for persons with dementia, etc. In Norway, institutions are 
categorised as either nursing homes or supported housing, the latter being housing rented or owned with care facilities attached or close by, but where there is no resident nursing staff (St.meld.nr.25).

In Denmark, the distinction between institutional and home care has become blurred in the last few decades. Since 1987 no conventional nursing homes have been built and housing arrangement is separated from service provision. Institutional care has been replaced by 24 - hour health and social supplied to all elderly in need, irrespective of housing. The 24-hour care is accessible every day for persons in acute need (Colmorten et al et al. 2003). The municipalities are obliged to ensure that those who cannot remain at home, even if they receive care at home, are admitted to a nursing home or another care facility staffed around the clock. An admission board in cooperation with the home help, home nursing and the GP assess whether an individual needs admission to a nursing home or increased services to stay at home. Denmark also has a more sophisticated and universal system for needs assessment than the other countries. Everyone aged 75 and over is entitled to at least two preventative visits by a district nurse annually (Schulz, 2010). Since 1996, users of home based services are also entitled to a contract that states what services the person is entitled to and how many hours she is entitled to (Platz and Brodhurst 2001).

Despite its high degree of reliance on formal care, the amount of informal care being provided in Scandinavian countries is considerable. In Denmark, 60 per cent of older people receive some form of help from their spouse, or from relatives and friends (Schulz, 2010). For Sweden, it has been estimated that the amount of help given by relatives to older people living at home is more than twice the amount given by local authorities. According to one study, as much as $70 \%$ of total service hours were provided by informal carers in 2000, and the share is likely to have increased during the last decade (Sundström et al, 2002; Sand, 2010). Over the last decade, the national government has started several initiatives to support informal carers. For carers who leave gainful employment in order to care for a severely ill family member, a family carer allowance can be applied for from the social insurance system (SALAR, 2009). Similar grants exist in Norway and Denmark as well (Helsetilsynet, 2009). The assignment is conditioned on the carer being suitable for the tasks and that the arrangement is best for the elderly. In Norway and Sweden, the systems are very similar. Carers receive a social security benefit from the central government and a rather modest care allowance from the municipalities. In Denmark the carer can claim compensation for foregone wages, and in this respect Denmark is fundamentally different from the other Scandinavian countries (Helsetilsynet, 2009).

\subsection{Volumes and Trends}

In 2008, about 250000 people 65 years of age and older received some kind of long-term care in Sweden, corresponding to 15.3 per cent of the entire elderly population. It is apparent that the need for care is highly age-related even among the elderly: among those 80 years of age and older, 37 per cent received some kind of long-term care in that year. The situation is similar in the other two countries, but in Norway, there has been a marked increase in the provision of services to people below the age of 67 years. During the last ten years, the number of clients below 67 years of age has almost doubled and now accounts for approximately 25 percent of the clients of LTC and for $37.1 \%$ of total LTC expenditure (Sintef 2009:147). This development is related to the de-institutionalisation of care for the young disabled. In Table 3, we have depicted recipients of home help and people living in institutions as percentages of the respective age groups for all three countries. 
Table 3. Coverage of LTC Services in Scandinavia 2007-08. Statistics from: NOSOCO, 2009

\begin{tabular}{||c|c|c|c|c|c|c||}
\hline & \multicolumn{3}{|c|}{ Institutional Care } & \multicolumn{3}{c||}{ Home Help } \\
\hline & Denmark $^{2}$ & Norway & Sweden $^{4}$ & Denmark $^{5}$ & Norway $^{6}$ & Sweden $^{7}$ \\
\hline $64-74$ & 1.2 & 2.4 & 1.2 & 6.3 & 3.4 & 2.3 \\
\hline $75-79$ & 3.6 & 6.2 & 4.2 & 18.1 & 8.2 & 7.4 \\
\hline $80+$ & 14.1 & 23.7 & 16.6 & 42.9 & 24.9 & 21.9 \\
\hline Total 65+ years & 5.0 & 10.8 & 6.4 & 18.1 & 12.1 & 9.2 \\
\hline$N$ & 48921 & 66528 & 106163 & 154571 & 74423 & n.a. \\
\hline
\end{tabular}

Source: NOSOSCO 2009. Social Protection in the Nordic Countries table 6.2.12 and 6.2.13

The emphasis of care tends to change somewhat over time. The trends in provision of home-based and institutional care for the Nordic countries are plotted in Figure 1. For the Scandinavian countries, as we see in the figure, there is a trend to scale down institutional care. The policy objective behind this trend is to make the elderly able to stay home as long as possible. The trend is particularly strong in Sweden but discernible also in Denmark, and this can be attributed to the Act on Housing for Older People (1987) which completely restricted the development of conventional nursing homes. Since 1987 no nursing homes have been built (Ministry of the Interior and Health 2005).

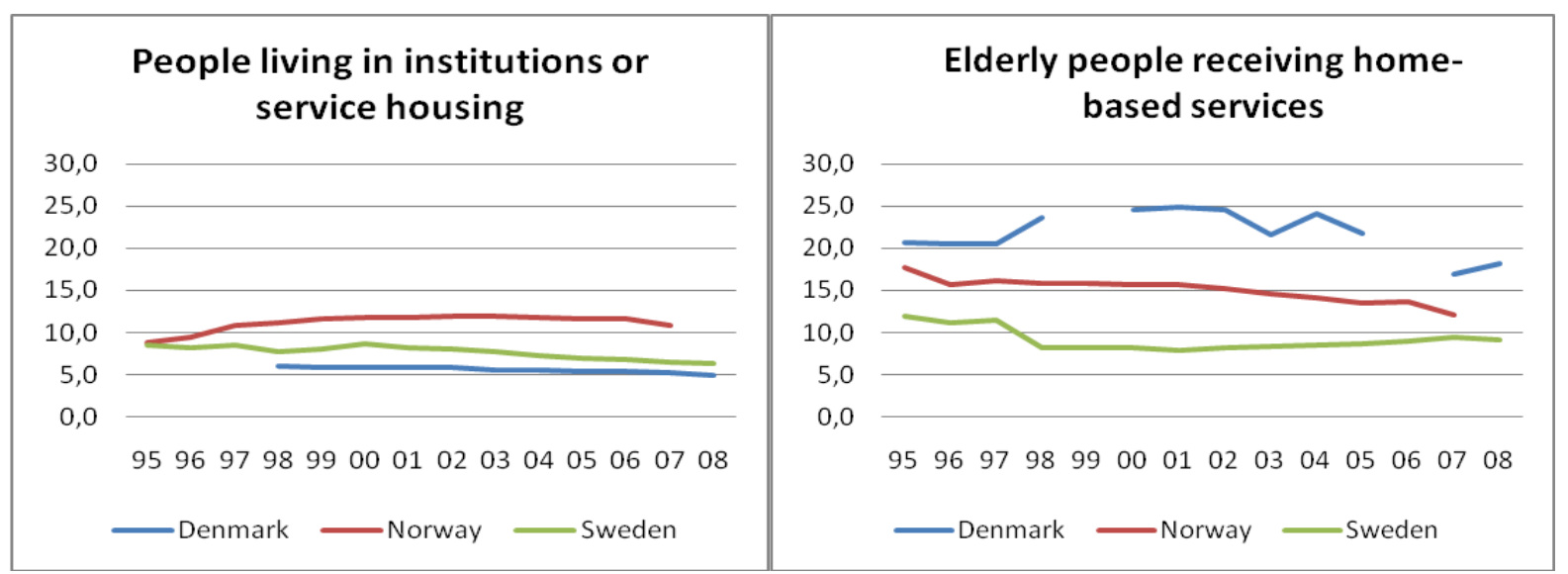

Figure 1. People living at institutions or in service housing and people receiving home help, as percentages of the age group 65 years or more, 1995-2008. Source: Nososco, 2009. Note: data for Denmark are only available with gaps

The trends in Sweden over the last 20 years are pictured in Table 4. It is clear that the trend to scale down public long-term care continued during the nineties, but that the pace of change has been

\footnotetext{
${ }^{2}$ Includes residents in nursing homes, sheltered housing, housing where care is provided and long-term stays in housing units. The figures for long-term stays in housing units are from 2008 and based on the age group 67-74 years.

${ }^{3}$ Age groups 67-74, 75-79 and 80+ years.

${ }^{4}$ Calculation as per 1 October 2006. The age group 65+ years furthermore includes people staying on a short-term basis and residents in service housing.

${ }^{5}$ Home help to residents in their own homes with the exception of service housing

${ }^{6}$ Age groups 67-74, 75-79 and 80+ years, including residents in service housing who receive practical assistance (home help) and home nursing. Recipients only receiving home nursing are not included.

${ }^{7}$ People who had been granted home help as at 1 October 2006 and who lived in their own houses or flats.
} 
considerably slower in the last decade. Furthermore, the share of LTC going to the oldest group has increased throughout the period, which can be seen by comparing the number of users amongst the $80+$ group to the total number of users.

Table 4. Recipients of Long-Term Care in Sweden 1993-2007.

\begin{tabular}{|c|c|c|c|c|c|c|c|c|c|c|c|c|}
\hline \multirow[b]{2}{*}{ Year } & \multicolumn{6}{|c|}{ Age 65- } & \multicolumn{6}{|c|}{ Age 80- } \\
\hline & $\begin{array}{c}\text { Domi- } \\
\text { ciliary } \\
\text { care }\end{array}$ & $\%$ & $\begin{array}{c}\text { Insti- } \\
\text { tution- } \\
\text { based } \\
\text { care }\end{array}$ & $\%$ & Total & $\%$ & $\begin{array}{c}\text { Domi- } \\
\text { ciliary } \\
\text { care }\end{array}$ & $\%$ & $\begin{array}{c}\text { Insti- } \\
\text { tution- } \\
\text { based } \\
\text { care }\end{array}$ & $\%$ & Total & $\%$ \\
\hline 1993 & 149,650 & 9.7 & 121,340 & 7.9 & 270,990 & 17.6 & 92,181 & 23.2 & 89,433 & 22.5 & 181,614 & 45.7 \\
\hline 1994 & 145,034 & 9.4 & 128,553 & 8.4 & 273,587 & 17.8 & 90,665 & 22.2 & 94,855 & 23.2 & 185,520 & 45.5 \\
\hline 1995 & 137,572 & 8.9 & 129,843 & 8.4 & 267,415 & 17.3 & 86,653 & 20.9 & 96,058 & 23.2 & 182,711 & 44.1 \\
\hline 1996 & 129,543 & 8.4 & 127,012 & 8.2 & 256,555 & 16.6 & 82,956 & 19.7 & 94,509 & 22.5 & 177,465 & 42.2 \\
\hline 1997 & 130,059 & 8.4 & 130,725 & 8.5 & 260,784 & 16.9 & 84,788 & 19.8 & 97,715 & 22.9 & 182,503 & 42.7 \\
\hline 1998 & 126,049 & 8.2 & 118,715 & 7.7 & 244,764 & 15.9 & 84,253 & 19.5 & 90,787 & 21.0 & 175,040 & 40.5 \\
\hline 1999 & 129,479 & 8.4 & 116,254 & 7.6 & 245,733 & 16.0 & 85,217 & 19.5 & 88,623 & 20.3 & 173,840 & 39.8 \\
\hline 2000 & 125,324 & 8.2 & 121,305 & 7.9 & 246,629 & 16.1 & 86,070 & 19.0 & 93,717 & 20.7 & 179,787 & 39.7 \\
\hline 2001 & 121,741 & 7.9 & 118,621 & 7.7 & 240,362 & 15.6 & 84,816 & 18.3 & 92,807 & 20.0 & 177,623 & 38.3 \\
\hline 2007 & 153,700 & 9.6 & 95,232 & 6.2 & 248,932 & 15.7 & 110,700 & 23.0 & 76,100 & 16.0 & 186,800 & 39.0 \\
\hline
\end{tabular}

Source: Socialstyrelsen (2002), SALAR (2009).

In Swedish domiciliary care, a restructuring could be observed in the nineties, where efforts were concentrated to the most severe cases. Thus, the number of elderly with weekly services amounting to 1-9 hours a month decreased significantly, whereas the share with services exceeding 50 hours increased. However, these trends have clearly been reversed during the last ten years (Socialstyrelsen, 2001, 2008).

In Denmark, services are not as concentrated on severe cases as in Sweden. Amongst care recipients living in their own home, 62 per cent receive less than 9 hours of care per month, and only 3 per cent receive more than 80 hours per month. These figures reflect the fact that there is no minimum level of need that older people need to meet to be eligible for home help (Schulz, 2010).

The figures presented so far conceal the fact that there is considerable variation between municipalities, in all countries, with regard to volume, composition and probably quality of LTC for the elderly. Table 5 shows the coverage of long-term care in Swedish municipalities (out of 290 in total) with the highest and the lowest cost per elderly. As might be noted, costs also vary significantly, and the differences are not completely attributable to differences in the age structure in the elderly population (cf. Karlsson et al, 2004). In Sintef (2009), regression analysis on Norwegian data shows that -- when controlling for morbidity and age structure -- local revenue, municipality size and population density all explain parts of the variation in LTC expenditure between municipalities. 
Table 5. Cost and Coverage of Long-Term Care in some Swedish Municipalities 2008. 8

\begin{tabular}{|c|c|c|c|c|c|c|}
\hline \multirow[b]{2}{*}{ Municipality } & \multirow[t]{2}{*}{$\begin{array}{l}\text { Cost } \\
\text { EUR }\end{array}$} & \multicolumn{2}{|c|}{$\begin{array}{l}\text { Home-based Care } \\
\text { Share of } 65+\text { Pop. }\end{array}$} & \multicolumn{2}{|c|}{$\begin{array}{c}\text { Institution-based Care } \\
\text { Share of } 65+\text { Pop. } \\
\end{array}$} & \multirow{2}{*}{$\begin{array}{c}\begin{array}{c}\text { Share of } \\
\text { population }\end{array} \\
65-w\end{array}$} \\
\hline & & Crude & Age Std. & Crude & Age Std. & \\
\hline Sorsele & 8,453 & 8 & 8 & 10 & 9 & 28.1 \\
\hline Berg & 7,931 & 14 & 13 & 7 & 6 & 24.7 \\
\hline Härjedalen & 7,816 & 10 & 9 & 8 & 7 & 25.4 \\
\hline Åsele & 7,804 & 12 & 11 & 8 & 7 & 28.4 \\
\hline Ragunda & 7,739 & 14 & 13 & 7 & 7 & 26.7 \\
\hline Nat. average & 3,309 & 9 & 9 & 6 & 6 & 17.8 \\
\hline & & & & & & \\
\hline Nykvarn & 3,625 & 5 & 8 & 3 & 5 & 13.1 \\
\hline Salem & 3,614 & 4 & 5 & 4 & 5 & 14.1 \\
\hline Håbo & 3,613 & 8 & 11 & 3 & 5 & 12.5 \\
\hline \begin{tabular}{|l} 
Vellinge \\
\end{tabular} & 3,542 & 12 & 14 & 3 & 3 & 18.1 \\
\hline Staffanstorp & 3,509 & 5 & 6 & 3 & 5 & 15.9 \\
\hline
\end{tabular}

Source: Socialstyrelsen (2009b)

\subsection{Composition of public and private providers}

Until the early nineties, Swedish long-term care was almost exclusively provided by local public monopolies. Private provision was limited to some complementary services like cleaning. There was also a broad political consensus that health and long-term care should be publicly provided.

In the early nineties, private entrepreneurs were allowed into the market for long-term care. In the first few years, a rapid expansion of private care took place; the share of private entrepreneurs in the municipal budgets for long-term care quadrupled. This trend continued at a somewhat slower pace throughout the nineties (Söderström et al, 2001), and it appears to have continued unabated during the last decade (SALAR, 2009; Socialstyrelsen, 2009b).

The impact of this change becomes clear if the shares of clients who are served by private caregivers are considered. These figures, which are given in Figure 2 show that private caregivers more than tripled their share after 1993.

\footnotetext{
8 'Crude' refers to the actual proportion of individuals, whereas 'Age Std' provides figures which have been corrected for differences in the age structure within the older group,
} 


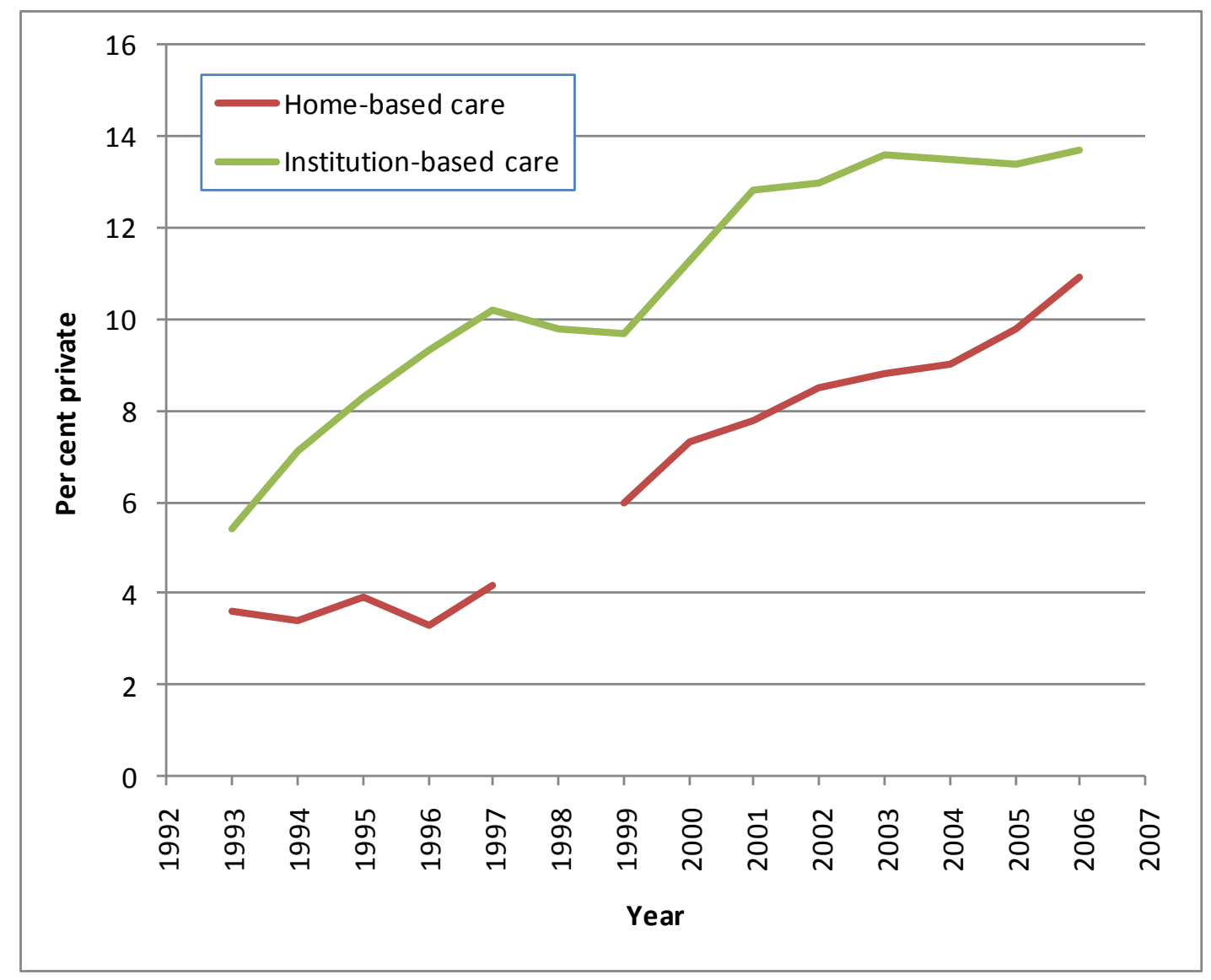

Figure 2. Proportion of Clients being assisted by Private Caregivers between 1993 and 2006. Source: Socialstyrelsen (2002b, 2008).

However, there are vast regional differences also in this case. The emergence of private caregivers is restricted to some 40 local authorities in metropolitan areas and some larger towns. In some of these, the presence of private caregivers has emerged as part of a consumer choice model, where the individual user may choose between competing providers. In other cases, the private element is simply the result of procurement at the local authority level. The development of consumer choice models has been actively supported by the current centre-right national government, and several municipalities have applied for earmarked funds to develop their own models (SALAR, 2009). A law regulating consumer choice models in public services was introduced in 2009, but even though a national system for consumer choice in primary care was introduced at the same time, it remains voluntary for the municipalities to introduce consumer choice models in LTC (SOU 2008:37).

In Denmark, on the other hand, consumer choice has been introduced universally by the national government. In 2002 a reform (the seniors' package) was enacted to secure the freedom of choice for the elderly. An older person who is entitled to subsidized housing is free to choose nursing home or special dwelling of their choice. Recipients of home-based care are also free to choose their preferred supplier. The local authorities must provide information on all providers that are approved to provide home-based services. The recipient can choose to have several providers; for instance, a public provider for personal help and a private supplier for practical help. Private suppliers within the long-term sector need to have a contract with the municipality to have the right to provide their 
services. The majority of the municipalities use the "approval model" that all providers that meet certain quality and price standards are approved as suppliers of home-based care services (Ministry of Interior and Health 2005). However, the Danish movement towards private provision started from a lower level than in Sweden: before the seniors' package, there were no private providers of home care in Denmark. Private commercial providers of home care are gaining an increasing share of the market, but they are mainly in the field of practical assistance. Even today, the market share of private companies remains below 5 per cent in personal care, and the forthcoming quality reform will seek to improve older people's knowledge of their possibilities to make an active choice of provider (Schulz, 2010).

In Norway, several municipalities have a tradition of contracting with non-profit nursing homes, even though public nursing homes dominate. Non-profit nursing homes are often owned and run by a religious or humanitarian organization. A contract with a municipality implies that their patients have been entitled to nursing home care similar to patients of public nursing homes. Apart from the city of Oslo, where some nursing homes have been put out to tender, there are no for-profit companies involved in publicly financed nursing homes in Norway. Also, within the home services, the proportion of private providers, is a lot smaller than in Sweden and Denmark. For practical and personal home help only a few of the municipalities have introduced consumer choice between public and private providers. In Oslo, there is a consumer choice model of home services and $21.5 \%$ of the recipients have chosen a private provider in 2010. Regarding home nursing, patient choice between public and private provider only exists in the city of Bergen in 2010. We conclude that both consumer choice and the combination of publicly financed and privately provided long term care is clearly more prevalent in Denmark and Sweden than in Norway. 


\section{Taxes and Risk adjustment}

A common factor in Scandinavian tax systems is the dual income tax structure, where capital incomes are taxed at a low and flat rate, whereas labour and transfer income is taxed progressively (Sørensen, 2009). However, the system for income taxation differs amongst Scandinavian countries in two important respects: firstly, the degree of progression is considerably lower in Norway than in Sweden and Denmark, and secondly, employers' social insurance contributions are much more important in Norway and Sweden than in Denmark, where marginal income taxes are correspondingly higher (OECD, 2009).

Swedish long-term care is mainly financed from local income taxes, which make up around $2 / 3$ of total revenue at municipality level. These general income taxes are charged by municipalities at a flat rate, averaging 20.74 per cent in 2010 . These taxes are determined by local politicians who have a considerable degree of autonomy (SCB, 2010). Although political preferences give rise to some local variation in tax rates (the span is currently between 18 and 24 per cent), the average level has been remarkably stable over the past 15 years. In Norway as well as in Denmark, the local tax base is broader than in Sweden, and includes wealth and property taxes as well. Nevertheless, local taxes are slightly less important as a revenue source than in Sweden (Statskontoret, 2009).

In addition to local taxes and out-of-pocket payments, the central governments contribute to the financing of long-term care through general grants paid to municipalities. In Sweden, such grants were introduced in 1993 and replaced a large number of earmarked grants. The current system consists of three main components: income adjustment, cost adjustment, and structural grants. In total, SEK 58 billion ( $€ 5.90 \mathrm{bn}$.) were transferred from the national government to local authorities in 2008, which corresponds to 17.6 per cent of their total revenues (SALAR, 2009b).

The overall objective of the government grants is to compensate for differences in tax bases and inherent differences in costs structures and thereby equalise the opportunities for local authorities to provide equivalent public services throughout the country. At the same time, local authorities shall not be compensated for differences in costs that are attributable to differences in service quality, user fees, or productive efficiency. The systems are very similar in the three countries, so we only report the particulars of the Swedish system here. The Swedish system for government grants has been reformed in 1996 and 2005, and smaller adjustments were implemented in 2008.

The income adjustment component in the system has the purpose to equalise the revenue side. The actual tax bases of the individual municipalities are compared to 115 per cent of the national average. Municipalities whose tax bases fall short of this benchmark level receive a payment from the national government equal to the shortfall multiplied by the regional average of local tax rates (Statskontoret, 2008). In order to avoid perverse incentives for municipalities with relatively strong tax bases, the fees levied on net contributors are calculated at a lower tax rate than the corresponding grant. In 2008, the national government paid SEK 52 bn. ( $€ 5.30$ bn.) in income adjustment grants to the 279 net receivers, and 11 well-off municipalities contributed another 3.7 bn (€0.38 bn.).

The cost adjustment component of the national grant is supposed to compensate for structural factors, such as demography, that are outside the municipalities' direct control. There are separate models for all different types of services that the municipalities are obliged to provide. For each such 
service, a 'standard cost' is calculated, and municipalities that exceed the standard cost receive a grant corresponding to the difference. This part of the system is symmetric, so municipalities with a favourable cost structure contribute the corresponding amount to the system.

In long-term care, the standard cost is calculated using a partition of the older population into 240 different cells, based on age, marital status and ethnic background. To each of these cells, a price tag is attached, which is based on the average costs of care at the national level. Not all components of this calculation are updated annually, however. Over and above the compensation for the standard costs thus calculated, there are special grants for institutional and domiciliary care in remote areas (Statskontoret, 2008). In 2008, the standard cost was SEK 8,410 (€855) per inhabitant, and in total, SEK 6.50 bn. ( $€ 661 \mathrm{M})$ were reallocated within the long-term care system.

The third main component of the government grant system, the structural grants, were introduced in 2005 with the intention to compensate municipalities that would otherwise have suffered considerable reductions in their grants due to the new system. Two further components are the temporary grants which were also introduced to compensate for changes to the system, and the adjustment grants ("regleringsbidrag"), which were introduced to allow the national government to transfer more resources to the local authorities than what the system stipulates. 


\section{User contributions: out of pocket payments, means testing and personal needs allowances}

In Sweden (as in the other two countries), only a small share of the expenditures on long-term care is financed through out-of-pocket payments; according to the most recent estimates, this share was 3.7 per cent in 2007 (SALAR 2009b), which is slightly less than the 5 per cent that were estimated 10 years ago (Karlsson et al, 2004). Thus, out-of-pocket payments are less important for LTC than in the financing of childcare (where the proportion is around 9 per cent) but nevertheless considerably higher than out-of-pocket payments in disabled care (at less than 1 per cent). Despite this, long-term care fees of different kinds make up a considerable share of individual income for many old people.

In the early nineties, municipalities were given considerable freedom in the design of the out-ofpocket payments. Some general principles were laid down in law. These principles are that fees should be fair, they may not exceed production cost, and they must leave a personal expenses allowance ("pocket money"). As it transpired that the municipalities made use of this freedom which resulted in a great degree of arbitrary variation in the levels and principles for calculating fees - some reforms to the system appeared to be necessary. Thus, in 2002 and 2003 the rules were tightened. Firstly, a national cap on out-of-pocket payment was introduced, stating that nobody shall have to pay more than a certain amount per month for personal services and for hotel costs, respectively. The caps are indexed to prices, and currently the cap for personal care is SEK 1,696 (€173) per month, and for hotel costs the maximum is 1,766 (€180) per month. Furthermore, the new law introduced a minimum personal needs allowance (currently SEK 4,787/€488 for singles and SEK 4,045/€412 per person for cohabiting partners). The reforms in 2002/03 also clarified how the user's income shall be calculated for means testing purposes, and opened up a possibility to appeal against unfavourable decisions (Socialstyrelsen, 2007).

In Norway, the general principles for out-of-pocket payments are similar to those in Sweden. For nursing homes, the user payment depends on whether the stay is short-term or long-term. The user contribution for a short-term stay is independent of the resident's income. The municipalities can charge a flat rate per night and there is a maximum allowable rate set by the central government (Stmeld.nr.25). In 2010 the rate for a day and night stay was NOK 125 (€15.80; HOD2010). For a long term stay the user payment depends on the resident's income. The municipalities are entitled to demand approximately 80 percent of the resident's income above a certain lower limit. In addition, the municipality is not allowed to charge more than the actual costs of the service and the recipient must be secured a minimum amount of pocket money for personal expenses. The user contributions include board and lodging and all health care services needed including medicines and physician services. The copayment does not depend on the amount of services used by the individual resident.

For older Norwegians living in their own housing or supported housing, the system of user payment is very different. In general, the regulation of user payments for health and care services correspond to the regulation that applies to the population at large. Older people living in supported housing other than nursing homes, pay housing expenses from their personal income. Public support for housing expenses may be applied for according to similar rules as for the general population. Primary health services are provided under the regular general practitioner scheme. Co-payments for physician services and medicines are according to the general regulation with an annual ceiling dependent on total co-payments and independent of an individual's income. 
For home help, Norwegian municipalities can freely choose the user payment to be charged as long as the payment is not above actual cost and the recipient is left with a minimum residual income (St.meld.nr25, 2005-2006). Many municipalities offer payment schemes with income dependent ceilings.

We observe that there is far greater degree of income dependent user payments for patients in nursing homes than there are for services to the elderly living at home. Hence, for older people with similar needs for care there will be less costly for a municipality to provide nursing home care to a person with a high income compared to a person with a low income.

In Denmark, there is no distinction in financing arrangement between institutional and home-based care. Residents in nursing homes pay rents approximated at the cost of housing and must also pay for other services such as electricity, meals, hairdressing, shaving etc. like for older people living in their own home. Home help and home nursing are provided free of charge irrespective of the type of housing (Colmorten et al, 2003). 


\section{Conclusions: efficiency and equity in Scandinavian LTC financing.}

The Scandinavian systems for financing long-term care are remarkably similar. The institutional setup is almost identical in the three countries: the local government carries the main responsibility for funding and provision of long-term care, and the national government defines general goals and principles for the locally provided services. These general goals and principles are also very similar between the countries. Differences between the three countries are notable only in the emphasis of different types of services, or in details concerning the design of schemes for user charges.

However, long-term care is a sector where two fundamental principles of the Scandinavian model appear to collide: it is difficult to reconcile the universalism of the Scandinavian welfare state with the political tradition of strong local autonomy. Thus, the models practiced for financing long-term care seem to be a compromise between these two general principles: municipalities have some degree of freedom in designing local policies, but the national government intervenes to assure that the conditions are comparable throughout the country.

In recent years, there has clearly been a trend towards favouring universalism at the expense of local autonomy. This trend is discernible in all three countries, but it takes on different forms in the different countries. In Sweden, the current national government tends to promote change on a voluntary basis, by providing funds that the local authorities can apply for in order to introduce new governance models in long-term care. In Denmark, on the other hand, much more emphasis has been on the rights of the individual user, and binding principles have been laid down in law. Clearly, the Swedish approach allows for more local experimentation, but it may also threaten universalism if other municipalities fail to follow successful pioneers.

Concerning the economic efficiency of the Scandinavian model, it is difficult to make a general assessment. Some aspects of the Scandinavian systems appear to further economic efficiency: first and foremost the fact that there is one dominant payer which covers the bulk of LTC spending. This standardised approach should give rise to considerable efficiency gains in comparison with the fragmented systems in Germany, the United Kingdom or the United States, where the funding of LTC typically comes from several different sources. Furthermore, the Scandinavian systems entail, at least in principle, a considerable degree of institutional competition. Since municipalities are obliged to provide services to each resident in need, individuals have the possibility to move to municipalities that provide particularly good services. The national risk adjustment systems assure that the free movement of individuals does not give rise to financial problems in the receiving municipalities.

On the other hand, there are some aspects of the Scandinavian model that appear to be suboptimal from an efficiency point of view. For example, in none of the countries, municipalities carry the main responsibility for health care. ${ }^{9}$ Since there are many situations where there is close substitutability between health and long-term care, there is a risk that local and regional authorities try to dump costly cases on each other. There have been tendencies to integrate some aspects of the two systems (cf. Schulz, 2010), but the risk of cost shifting is always there as long as there are two

\footnotetext{
${ }^{9}$ In Denmark, health care is the responsibility of the regional level of government, in Sweden health care is the responsibility of the county councils and in Norway, primary care is the responsibility of the municipalities and and specialist health care is the responsibility of the national government.
} 
different payers with partly different objectives. Furthermore, the user charges in health and longterm care tend to be different, so there may also be an incentive on the part of the individual user to pick the most favourable system.

Moreover, the non-existence of private LTC insurance may be interpreted as an indication of inefficiencies in the design of the public subsidy. For some individuals, user charges may amount to a substantial share of their individual income (e.g. in Norway, as much as 80 per cent of an individual's income may be claimed as a payment for nursing home care). Risk averse individuals would naturally wish to insure this risk, and thus, it appears that the public sector crowds out the demand for private insurance, just as it does in the United States (cf. Brown and Finkelstein, 2007). This crowding out is generally expected whenever benefits from private insurance lead to a reduction in the public subsidy; i.e., when insurance benefits count as income in the means testing procedure. However, given that there is no requirement in Scandinavian countries to spend down assets before an individual becomes eligible for public support, the absence of private insurance might simply reflect that individuals put a low value on protecting their income in the contingency that they need longterm care.

Concerning equity, there are many different dimensions of equity that need to be taken into consideration. Hence, an equitable LTC system should strike the right balance between those who need care and those who do not; between young and old (since otherwise the political sustainability of the system might be in peril); between poor and rich - which a greater challenge than for income taxes in general, since there are important differences between rich and poor not only concerning resources available, but also in terms of care needs and life expectancy. Furthermore, equity between men and women has often been overlooked in discussions concerning LTC, but this issue is of tremendous importance, considering the fact that women provide the bulk of informal (i.e. unpaid) care to frail spouses or parents, whereas men tend to contribute more to the funding of public LTC services, but get less back from the system in terms of care. Thus, the design of an LTC system will inevitably have strong implications for discussions of gender equality (Karlsson, 2007).

The great regional variation in coverage levels, quality of services, eligibility criteria and consumer choice clearly seems to be inequitable, particularly in view of the Scandinavian welfare states' universalist ambitions. Another important issue is whether informal carers receive sufficient compensation: given that there are no legal obligations to care for a frail family member, it would seem inequitable if family carers do not receive full compensation for their work. On the other hand, the design of Scandinavian LTC systems appear to promote gender equality: the heavy reliance on public funding and formal care services implies that there is relatively low pressure on middle-aged females to give up gainful employment in order to care for frail family members, and furthermore, there is a considerable degree of redistribution from males to females in the systems.

The LTC sectors in Scandinavian countries will face important challenges due to changes in the composition of the population. This is partly due to each country gradually becoming more heterogeneous due to immigration from non-European countries. Since the tradition that children take care of their frail parents is stronger in these countries, the willingness to pay for publicly financed LTC may decline. More important is perhaps the change in the age composition that is taking place. Contrary to health care, where remaining time to death seems to be the dominating demographic factor that determines expenditures, LTC expenditures seem to depend on the age in 
itself. In Denmark the number of older people 80 years and above is expected to double from 224,000 to 457,000 in 2040 (De Økonomiske Råd, 2009). The expected percentage increase is similar in Norway and Sweden. For Norway, it is estimated (assuming constant productivity) that the number of personnel in the LTC sector has to double towards the middle of the century in order to maintain today's level of quality (St.meld. nr. 9, 2008-2009). Hence, demographic trends are likely to entail important challenges both regarding the number of personnel needed and for maintaining public and universal funding of long term care. 


\section{References}

Anttonen, A. And J. Sipilä (1996), "European Social Care Services: Is It Possible To Identify Models ?", Journal of European Social Policy, Vol. 6, No. 2, 87-100

Brown, J. and A. Finkelstein (2007) "Why is the market for long term care insurance so small?". Journal of Public Economics 91(10): 1967-1991.

Colmorten, E., Clausen, T. and Bengtsson S. (2003), Providing integrated health and social care for older persons in Denmark. The Danish National Institute of Social Research, Copenhagen.

Daatland, Svein Olav and Gert Sundström (1997), "Synsvinkel og tilnærming", in Daatland, Svein Olav (ed., 1997), De siste årene. Eldreomsorgen i Skandinavia 1960-95. Nova-Rapport 22/1997.

Daatland, Svein Olav, Merete Platz and Gert Sundström (1997), "Status og utviklingslinjer", in Daatland, Svein Olav (ed., 1997), De siste årene. Eldreomsorgen i Skandinavia 1960-95. NovaRapport 22/1997.

De økonomiske råd (2009), Konjunkturvurdering - Sundhed. København: De økonomiske råd.

Esping-Andersen, G. (1990), The Three Worlds of Welfare Capitalism, Princeton University Press, Princeton.

EUROSTAT 2010, Data on health care expenditure on long-term care. Downloaded 15.04.2010 from ec.europa.eu/eurostat,

Hansen, E. B. (2000) Social protection for dependency in old age in Denmark. In Modernising and improving EU social protection: Conference on long-term care of elderly dependent people in the EU and Norway, June 17-18, 1998. London: Departement of Health Publications

Helse- og omsorgsdepartementet (HOD) (2009), Rundskriv: Endring av fribeløp og egenandeler for kommunale pleie- og omsorgstjenester. Oslo 2009

Helsetilsynet (2009) Omsorgslønnsordningen - en kunnskapsoppsummering. Internserien 7/2009. Statens helsetilsyn, Oslo.

Huseby, B. M. and Paulsen, B. (2009) SINTEF Rapport, Eldreomsorgen I Norge: Helt utilstrekkelig eller best $i$ verden. Trondheim: SINTEF

Karlsson, M., L. Mayhew, R. Plumb and B. Rickayzen (2004), An international comparison of LTC Arrangements. An investigation into the equity, efficiency and sustainability of Long-Term Care Systems in Germany, Japan, Sweden, the United Kingdom and the United States. Actuarial Research Paper No. 156, Cass Business School.

Karlsson, Martin (2007), "Distributional Effects of Reform in Long Term Care", Ageing Horizons No. 6, pp. 133-41.

Korpi, W. \& Palme, J. (1998), "The paradox of redistribution and strategies of equality: Welfare state institutions, inequality, and poverty in the western countries", American Sociological Review 63, $661-687$ 
Ministry of the Interior and Health and Ministry of Social Affairs (2005), Report on health and longterm care in Denmark. Copenhagen: Ministry of the Interior and Health and Ministry of Social Affairs.

Nordic Social-Statistical Committee (2009), Social Protection in the Nordic Countries. Scope, expenditure and financing 2007/2008. Copenhagen: Nordic Social-Statistical Committee.

OECD (2009), Taxing Wages. Paris: OECD.

Platz, M. and Brodhurs, S. (2001), Denmark. Ch. 3 in Blackman, T. (ed) Social Care and Social Exclusion. A Comparative Study of Older People's Care in Europe, Basingstoke, Palgrave.

Rothstein, B. (1998), Just Institutions Matter, Cambridge University Press

SALAR (2009), Developments in Elderly Policies in Sweden. Stockholm: SALAR.

SALAR (2009b), Ekonomirapporten. Om kommunernas och landstingens ekonomi - oktober 2009. Stockholm: SALAR.

Sand, Ann-Britt (2010), Anhöriga som kombinerar förvärvsarbete och anhörigomsorg, Kunskapsöversikt 2010:1, Nationellt Kompetenscentrum Anhöriga.

SCB (2010), Kommunalskatterna 2010. Statistiskt Meddelande SM1001. Stockholm: Statistics Sweden.

Schulz, Erika (2010), The long-term care system in Denmark. Working paper, DIW Berlin.

Socialstyrelsen (2001), Nationell handlingsplan för äldrepolitiken. Lägesrapport 2001. Stockholm: Socialstyrelsen.

Socialstyrelsen (2002), Socialtjänstlagen - Vad gäller för dig från 1 januari 2002? Stockholm: Socialstyrelsen.

Socialstyrelsen (2002b), Nationell handlingsplan för äldrepolitiken. Lägesrapport 2002. Stockholm: Socialstyrelsen.

Socialstyrelsen (2007), Uppdrag att följa upp och utvärdera socialtjänstlagens bestämmelser om avgifter inom äldre- och handikappomsorgen.

Socialstyrelsen (2008), Äldre - vård och omsorg 2007. Stockholm: Socialstyrelsen.

Socialstyrelsen (2008b), Vård och omsorg om äldre. Lägesrapport 2007.

Socialstyrelsen (2009), Care of Older People in Sweden 2008, Stockholm: Socialstyrelsen.

Socialstyrelsen (2009b), Jämförelsetal för socialtjänsten år 2008.

Söderström et al (2001), Privatiseringens gränser. Perspektiv på välfärdspolitiken. Stockholm: SNS Förlag.

Søgaard, J (2009), International Reliability of SHA Total Expenditure on Health. Working Paper, Danish Institute for Health Services Research. 
Sørensen, Peter B. (2009), Dual Income Taxes: A Nordic Tax System. Mimeo, University of Copenhagen.

SOU 2008:37, Vårdval i Sverige. Stockholm: SOU.

Statskontoret (2008), Det kommunala utjämningssystemet - en förstudie. Stockholm: Statskontoret.

Statskontoret (2009), Kommunal utjämning i Danmark, Norge och Finland. Stockholm: Statskontoret.

St.meld. nr. 25 (2005-2006), Mestring, muligheter og mening. Framtidas omsorgsutfordringer. Oslo: Det kongelige Helse- og omsorgsdepartement.

St.meld. nr. 9 (2008-2009)Perspektivmeldingen 2009. Oslo: Finansdepartementet

Sundström G, Johansson L, Hassing LB (2002), "The shifting balance of long-term care in Sweden", Gerontologist, Jun;42(3):350-5.

Titmuss, R. A. (1974), Social Policy, Allen and Unwin, London.

Wittenberg and Malley (2007), "Financing Long-Term Care for Older People in England", Ageing Horizons 6: 28-32. 